\title{
Editorial
}

\section{Oral Medicine and Oral Surgery: two sides of the same coin}

\author{
Nathan Moreau* \\ Department of Oral Medicine and Oral Surgery, Bretonneau Hospital, AP-HP, Paris, France
}

(Received: 19 July 2021, accepted: 26 July 2021)

\author{
"A good surgeon is an internist who can operate." \\ Traditional surgical aphorism [1]
}

\section{Dear Editor,}

In addition to the current residency curricular reform ("Réforme du $3^{\text {ème }}$ cycle" or R3C in short) and another - highly understandable - medical resident strike (pertaining to their unacceptable weekly working hours), 2021 is also the 10-year anniversary of our "new" surgical specialty, cursorily named "Oral Surgery", an appropriate time to reflect on the strengths and pitfalls of the curriculum implemented so far.

In an editorial from 2016, whilst discussing the current situation of Oral Medicine practice in France and lack of formal specialty (as opposed to numerous other countries who have Oral Medicine specialists), Pr Jean-Christophe FRICAIN aptly raised an important question: Will Oral Surgery save Oral Medicine? [2]. Nevertheless, I believe that the converse question could also be raised: Will Oral Medicine save Oral Surgery?

Considering the aforementioned lack of specialty training in Oral Medicine, both in medical and dental practices, Oral Surgery is - by necessity - a "medico-surgical" specialty (to use the French expression), similarly to otorhinolaryngology for instance. Nevertheless, as previously suggested, I strongly believe Oral Surgery to be a "medico-surgical" specialty not (only) by necessity but by nature, Oral Medicine and Oral Surgery being but two sides of the same coin [3]. In a period when more and more residents are turning towards lifestyle surgical specialties (i.e. better pay, better work/life balance, fewer hours) [4], including private practice-performed Oral Surgery, this issue is far from trivial.

As academics, if we do not sufficiently promote the - unfortunately less considered and less remunerated - Oral Medicine part of our specialty, the consequences for the patients will be dire and our specialty will clearly not flourish as hoped.

From an historical perspective, it is interesting to note that the arbitrary separation between Medicine and Surgery, still prevailing today to some extent, has been the subject of much

\footnotetext{
*Correspondence: nathan.moreau@aphp.fr
}

discussion, as least as early as the VIIIth century BC, where Sushruta admonished against such separation "just as only a two-wheeled cart can be of service in the field of battle" [5]. Furthermore, throughout History, Surgery has gained in respectability when surgeons started training in medical faculties (despite the objections of medical doctors!), progressively abandoning the "lowly" condition of the barber for the more prestigious title (and competency) of surgeon.

From a medical perspective, Oral Medicine and Oral Surgery are indeed complementary, the first being the indication of the second, but also the prerequisite for a safe and useful intervention. It stands to reason that if the oral surgeon performs a surgical procedure for an improperly-diagnosed condition, there is significant risk of diagnostic delay and iatrogeny with foreseeable medical and legal consequences. Table I illustrates several -non-exhaustiveexamples of the complementarity of Oral Medicine and Oral Surgery, and the possible consequences of insufficient knowledge of Oral Medicine in various surgical procedures, as supported by personal experience and the available literature [6-17].

From a medicolegal perspective, failure to diagnose oral diseases or oral manifestations of systemic diseases is a frequent cause of litigation [18], especially in cases of misdiagnosed cancerous lesions [19]. Furthermore, unjustified tooth avulsions in cases of misdiagnosed non-odontogenic tooth pain are progressively becoming additional causes of litigation, even in France (for an example, see [20]).

All in all, one can only advocate for better training in Oral Medicine including (but not limited to) Oral Mucosal diseases, Jawbones diseases, Oral Pathology and Orofacial pain $[3,21]$, in adherence with the French bylaw of October 18, 2017 legislating the training of oral surgeons.

Without specific guidelines, our residents will - quite pragmatically - focus their training on the better-remunerated activities that will make up an important part of their future private practice, such as implantology and preimplant surgery. Although dental implant-related surgery is indeed an important part of the oral surgeon's scope of practice (including preimplant surgery and plastic periodontal surgery), one should not omit the rest of the specialty's scope, for the benefit of both patient and surgeon. 
Table I. Non exhaustive examples of the complementarity between oral surgical procedures and necessary Oral Medicine knowledge with resulting possible consequences in cases of insufficient or erroneous knowledge.

\begin{tabular}{|c|c|c|}
\hline $\begin{array}{l}\text { Surgical } \\
\text { procedure }\end{array}$ & Oral Medicine knowledge required & $\begin{array}{l}\text { Possible consequences of insufficient or } \\
\text { erroneous Oral Medicine knowledge }\end{array}$ \\
\hline \multirow{3}{*}{$\begin{array}{l}\text { Oral mucosal } \\
\text { lesion biopsy }\end{array}$} & Most informative region to biopsy & False negative biopsy and subsequent diagnostic delay [6] \\
\hline & $\begin{array}{l}\text { Oral lesions suggestive of systemic } \\
\text { involvement }\end{array}$ & $\begin{array}{l}\text { Severe hemorrhage in case of unsuspected thrombopenia } \\
\text { (e.g. in acute myeloid leukemia) [7] }\end{array}$ \\
\hline & $\begin{array}{l}\text { Histopathological aspects of oral mucosal } \\
\text { diseases (to allow precise clinico- } \\
\text { pathological correlations) }\end{array}$ & $\begin{array}{l}\text { Improper diagnosis (and thus treatment) if the pathologist } \\
\text { cannot precisely diagnose the disease from the specimen } \\
\text { provided and neither can the surgeon [6] }\end{array}$ \\
\hline \multirow[t]{2}{*}{ Tooth avulsion } & $\begin{array}{l}\text { Differential diagnoses of tooth pain } \\
\text { (underlying the referral to the oral surgeon) }\end{array}$ & $\begin{array}{l}\text { Unjustified avulsion with foreseeable medicolegal } \\
\text { consequences but also severe morbidity and/or mortality } \\
\text { in case of referred tooth pain caused by cervical artery } \\
\text { dissection [8], stroke [9], cancer [7,10] or cardiac } \\
\text { ischemia [11] }\end{array}$ \\
\hline & $\begin{array}{l}\text { Differential diagnoses of tooth mobility } \\
\text { (underlying the referral to the oral surgeon) }\end{array}$ & $\begin{array}{l}\text { Diagnostic delay in case of epidermoid carcinoma or other } \\
\text { oral cancers [12] }\end{array}$ \\
\hline $\begin{array}{l}\text { Odontoma / } \\
\text { supernumerary } \\
\text { tooth removal }\end{array}$ & $\begin{array}{l}\text { Hereditary cancer syndromes with orofacial } \\
\text { manifestations }\end{array}$ & $\begin{array}{l}\text { Lack of possible prevention of colorectal cancer in case of } \\
\text { undiagnosed Gardner syndrome [13] }\end{array}$ \\
\hline $\begin{array}{l}\text { Cyst } \\
\text { enucleation }\end{array}$ & $\begin{array}{l}\text { Radiological semiology of odontogenic and } \\
\text { non odontogenic cysts and relevant } \\
\text { differential diagnoses }\end{array}$ & $\begin{array}{l}\text { - Erroneous treatment option not taking into account the } \\
\text { risk of recurrence or potential malignancy [14] } \\
\text { - Major (if not fatal) hemorrhage in case of undiagnosed } \\
\text { arteriovenous malformation [15] or central hemangioma } \\
\text { [16] }\end{array}$ \\
\hline $\begin{array}{l}\text { Endodontic } \\
\text { surgery }\end{array}$ & $\begin{array}{l}\text { Differential diagnoses of periapical } \\
\text { lucencies }\end{array}$ & $\begin{array}{l}\text { Misdiagnosed actinomycosis [17] or lymphoma [10] } \\
\text { (especially in the absence of histopathological analysis of } \\
\text { removed periapical tissue) }\end{array}$ \\
\hline
\end{tabular}

As academic oral surgeons (and thus oral medicine specialists as well), we must be vigilant to maintain the balance and complementarity of Oral Medicine and Oral Surgery during residency training. The following issues are worthy of consideration:

- Sufficient time and patient exposure should be given to the residents during their clerkships in academic centers to train in the various aspects of Oral Medicine, especially by integrating them systematically in the relevant tertiary clinics.

- All academic centers should have dedicated tertiary clinics focusing on all aspects of Oral Medicine as previously mentioned, namely: Oral Mucosal diseases, Oral Radiology, Jawbone diseases and Orofacial pain. Unfortunately, to this day, not all academic centers have such clinics in their hospitals (or affiliated clinics in other hospitals).

- Better recognition of Oral Medicine practice should be sought for, leading to better remuneration of such specialized consultation activities. This could become a goal of the expert group on oral mucosal diseases (Groupe d'Etude de la Muqueuse Buccale, GEMUB), under the leadership of the senior academics in the field.
- All residents should receive extensive training in Oral Oncology and significant training in systemic diseaseassociated Orofacial pain, so as to mitigate the risk of diagnostic delay and subsequent morbidity and/or mortality, even in the context of a high-paced private practice. Specific nationwide curricular activities could be developed to allow such - ideally mandatory - training.

- As Oral Medicine practice is a time-consuming activity, it currently is solely a hospital-based clinical activity, thus falling under the responsibility of the public sector. This should be taken into consideration when training future (public) hospital practitioners and academic oral surgeons.

In the end, how will Oral Medicine save Oral Surgery?

The "new" specialty of Oral Surgery will only be able to earn its stripes when encompassing the full extent of its scope of practice, which includes Oral Medicine and associated highburden/high-morbidity diseases. By embracing the naturallycomplementary activities of Oral Surgery and Oral Medicine, as previously suggested [2], the oral surgeon will gain significant competency, legitimacy and efficacy, raising the field to its deserved status of true "medico-surgical" specialty. 


\section{References}

1. Schein M. Aphorisms and quotations for the surgeon. tfm Publishing; 2003:230.

2. Fricain JC. La chirurgie orale sauvera-t-elle la medicine orale? Med Bucc Chir Bucc 2016;22:161-2.

3. Moreau N. Rethinking the scope of oral medicine/oral surgery practice: 7 unusual must-know conditions for the oral surgeon. J Oral Med Oral Surg 2019;25:24.

4. Levaillant M, Levaillant L, Lerolle N, Vallet B, Hamel-Broza JF. Factors influencing medical students' choice of specialization: A gender based systematic review. E Clin Med 2020;28: 100589.

5. Bhishagratna KKL. An English translation of the Sushruta Samhita - Volume I - Sutrasthanam, Calcutta, 1907; Chapter III, p. 30.

6. Kumaraswamy KL, Vidhya M, Rao PK, Mukunda A. Oral biopsy: oral pathologist's perspective. J Cancer Res Ther 2012;8: 192-9.

7. Suarez-Cuenca JA, Arellano-Sanchez JL, Scherling-0campo AA, Sanchez-Hernandez G, Perez-Guevara D, Chalapud-Revelo JR. Rapidly progressing, fatal and acute promyelocytic leukaemia that initially manifested as a painful third molar: a case report. J Med Case Rep 2009;3:102.

8. Roz TM, Schiffman LE, Schlossberg S. Spontaneous dissection of the internal carotid artery manifesting as pain in an endodontically treated molar. J Am Dent Assoc 2005;136: 1556-9.

9. Goel R, Kumar S, Panwar A, Singh AB. Pontine infarct presenting with atypical dental pain: a case report. Open Dent J 2015;9: 337-9.

10. Hassona Y, Almuhaisen G, Almansour A, Scully C. Lymphoma presenting as a toothache: a wolf in sheep's clothing. BMJ Case Rep 2017;2017:bcr2016218686.
11. Okajima Y, Hirai A, Higashi M, Harigaya K. Vasospastic angina in a 13-year-old female patient whose only symptom was toothache. Pediatr Cardiol 2007;28:68-71.

12. Suzuki K, Shingaki S, Nomura T, Nakajima T. Oral carcinomas detected after extraction of teeth: a clinical and radiographic analysis of 32 cases with special reference to metastasis and survival. Int J Oral Maxillofac Surg 1998;27:290-4.

13. Jones K, Korzcak P. The diagnostic significance and management of Gardner's syndrome. Br J Oral Maxillofac Surg 1990;28:80-4.

14. Tabrizi R, Omidi M, Dehbozorgi M, Hekmat M. Correlation of radiographic features and treatments with the frequency of recurrence in odontogenic keratocysts of the mandible. J Craniofac Surg 2014;25:e413-7.

15. Kriwalsky MS, Papadimas D, Maurer P, Brinkmann M, Jackoski J, Kunkel M. Life-threatening bleeding after tooth extraction due to vascular malformation: a case report and literature review. Oral Maxillofac Surg 2014;18:279-82.

16. Lamberg MA, Tasanen A, Jääskeläinen J. Fatality from central hemangioma of the mandible. J Oral Surg 1979;37:578-84.

17. Nair PNR. On the causes of persistent apical periodontitis: a review. Int Endod J 2006;39:249-81.

18. Melrose RJ. Failure to diagnose pathology: an avoidable complication in oral and maxillofacial surgery. Oral Maxillofac Surg Clin North Am 2011;23:465-73.

19. Epstein JB, Kish RV, Hallajian L, Sciubba J. Head and neck, oral, and oropharyngeal cancer: a review of medicolegal cases. Oral Surg Oral Med Oral Pathol Oral Radiol 2015;119:177-86.

20. Décision de la Cour d'Appel de Basse Terre du 26 octobre 2020, n¹6/006971; available at: https://www.dalloz.fr/documenta tion/Document?id=CA_BASSETERRE_2020-10-26_16006971\#_

21. Pinto A, Khalaf M, Miller CS. The practice of oral medicine in the United States in the twenty-first century: an update. Oral Surg Oral Med Oral Pathol Oral Radiol 2015;119:408-15. 